\title{
Cinnamomum: review article of essential oil compounds, ethnobotany, antifungal and antibacterial effects
}

\begin{abstract}
Aromatic as well as medicinal plant species have played important roles in the lives of tribal people living in the Himalaya by providing products for both food and medicine. This review presents a summary of ethonobotanical, antibacterial, antifungal and volatile compounds of essential oils of some Cinnamomum species from the Nepal, Assam, Karnataka, and Indian Himalaya. This review illustrates the various prospective of cinnamon and its use in daily life.
\end{abstract}

Keywords: Cinnamomum, ethonobotany, antifungal, antibacterial, essential oil, India, food and medicine
Volume 3 Issue I - 2019

\author{
Sanjay Kumar,' Reshma Kumari \\ 'Department of Botany, D.S.B. Campus, Kumaun University, India \\ ${ }^{2}$ Department of Botany \&Microbiology, Gurukul Kangri \\ University, India
}

\begin{abstract}
Correspondence: Reshma Kumari, Department of Botany \&Microbiology, Gurukul Kangri University, Haridwar 249404, Tel +91-8755388I32India, Email reshmagupta25@gmail.com
\end{abstract}

Received: January 18,2019 | Published: January 29, 2019

\section{Introduction}

Spices played an important role in the history of exploration and development, are no longer luxury items of great cost. With the advent of refrigeration, there is less demand in the west to preserve and flavour foods at home, but they are widely used by the meat, sauce, canning, frozen food industries, and food manufacturing industry generally. They are also used in the cosmetic and perfumery industries, including its use in soap and toothpaste. Spices, or their essential oil, are of some importance in the preparation of liqueurs and cordials. They are also used in various ayurvedic and allopathic medicine. Bakers use it liberally in cookies and in hot drinks. Cinnamomum are said to be among the oldest spices Cinnamomum has fragrant, sweet and warm taste. Commercial essential oil production industry used several aromatic plant species for extracting high quality essential oil. Cinnamon is a highly valued spice whose bark is widely used as a spice. It is mainly used in cookery as a spice and by various industries for foodstuff, flavouring agent for fragrance and essence perfumes, and medicinal products. ${ }^{1}$ Cinnamomum stands out of all spices in its "warmth" and ranks as second to pepper. As spices, cinnamon is considered one of the finest sweet spices.

It is indigenous in Sri Lanka, which still produces the largest quantity and best quality, mainly in the form of quills. This genus contains evergreen trees or shrubs belongs to Lauracaceae family contain around 250 species in tropical and subtropical regions, mostly in Asia and some in South and Central America, and Australia ${ }^{2}$ however, in Himalayan region only eight species i.e. Cinnamomum bejolghota (Buch.-Ham.) Sweet, Cinnamomum camphora (L.) J. Presl, Cinnamomum glanduliferum (Wall.) Meisn, Cinnamomum glaucescens (Nees) Hand.-Mazz., Cinnamomum impressinervium Meisn., Cinnamomum parthenoxylon (Jack) Meisn., Cinnamomum tamala (Buch.-Ham.) Nees and Eberm., and Cinnamomum zeylanicum Breyn is found Imani et al., ${ }^{3}$ reported noticeable improvement in digestion, as well as appetite stimulating properties in recent research. In another report, Vangalapati et al. ${ }^{4}$ reported that in ancient Egypt cinnamon was used for beverage flavouring, as well as to treat illnesses. Moreover, it has been frequently used in savoury cuisines, Persian sweets soups and pickles. In conventional Chinese medicine, cinnamon has been used as a potential neuroprotective agent, ${ }^{5}$ as well as a potent medicine for the control and treatment of type 2 diabetes mellitus. ${ }^{6}$ Cinnamomum species are commercially valuable source of camphor, cinnamaldehyde and safrol oil in the world. This review presents a summary of Cinnamomum species from the Indian Himalaya, Nepal, and Bhutan, focusing on their ethnobotanical uses with the volatile compounds.

\section{Methodology}

The current review was conducted using a complete and organized search of the available literature on the medicinal plant cinnamon by using the keywords: essential oil, Himalaya, India, Nepal, Assam, Karnataka, and Indian Himalaya. The searches were performed using various databases, including PubMed (http://www.ncbi.nlm.nih.gov/ pubmed), Science Direct (http://www.sciencedirect.com/), Scopus (http://www.scopus.com/), Scirus (http://www.scirus.com/), and Google Scholar (http://www.scholar.google.com/).

\section{Distribution}

Sri Lanka is the major Cinnamon growing country along with Seychelles, Madagascar and India. ${ }^{7}$ Best quality of cinnamon bark, mainly as quills is produced by Sri Lanka. Sri Lanka and Seychelles have approx 24,000 ha and 3400 ha area under cultivation producing around 12,000 $\mathrm{t}$ and $600 \mathrm{t}$ cinnamon respectively. ${ }^{8}$ Cinnamon leaf oil is mostly produced in these countries, though the bark oil is distilled mostly in the importing countries. Sri Lankan export is to the tune of around $120 \mathrm{t}$ of leaf oil and 4-5 $\mathrm{t}$ of bark oil. ${ }^{9}$

\section{Cultivation of cinnamon}

Around 27,000-35,000 annual tons cinnamon is globally produced. ${ }^{10}$ It is mostly raised in China, Seychelles, Madagascar and Sri Lanka; additionally, it's cultivated on a little scale in Vietnam and India. It's a hardy plant in terms of its suitableness for its cultivation in various weather conditions. The optimal temperature for the cultivation of cinnamon ranges between 20 to $30^{\circ} \mathrm{C}$, with a yearly rainfall ranging between 1250 to $2500 \mathrm{~mm}$. Cinnamon is usually propagated by dried seed and vegetative propagation (Table 1). ${ }^{11}$ 
Table I Ethnopharmacological uses, essential oil compositions, and any biological activities of the essential oils of Cinnamomum species

\begin{tabular}{|c|c|c|c|}
\hline Plant Name & Ethnopharmacology & Antifungal and Antimicrobial & Essential oil \\
\hline $\begin{array}{l}\text { C. camphora } \\
\text { (L.) J. Presl }\end{array}$ & $\begin{array}{l}\text { Bronchitis, cold, } \\
\text { congestion, diarrhea, } \\
\text { dysentery, edema, } \\
\text { influenza, flatulence, } \\
\text { metabolic and heart } \\
\text { problems, gynecological } \\
\text { problems }^{15}\end{array}$ & $\begin{array}{l}\text { leaf oils: antifungal activity against Choanephora cucurbitarum } \\
\text { and antibacterial activity against Pasturella multocida }{ }^{17} \text { and } \\
\text { Aspergillus niger; }{ }^{18} \text { leaf oil sample from Nepal had shown } \\
\text { notable allelopathic activity, cytotoxic activity against MCF-7 } \\
\text { human breast tumor cells, and insecticidal activity (Chaoborus } \\
\text { plumicornis, Pieris rapae, Drosophila melanogaster, Solenopsis } \\
\text { invicta } x \text { richteri); }{ }^{18} \text { camphor has shown antibacterial activity } \\
\text { against the respiratory pathogen Haemophilus influenza }{ }^{19}\end{array}$ & $\begin{array}{l}\text { Essential oil chemotypes: (I) camphor, } \\
\text { (2) linalool, ( } 3 \text { ) I,8-cineole, (4) nerolidol, } \\
\text { and (5) borneol; }{ }^{20} \text { Leaf oil from Pantnagar, } \\
\text { Uttarakhand: camphor ( } 82.4 \%) \text { (Agarwal et } \\
\text { al., } 2012 \text { ) from Nukuchiatal, Uttarakhand: } \\
\text { camphor (8I.5\%), }{ }^{21} \text { from Hetauda, } \\
\text { Makwanpur, Nepal: camphor ( } 36.5 \%) \text {, } \\
\text { camphene (II.7\%), limonene ( } 9.0 \%) \text {, sabinene } \\
(6.3 \%), \beta \text {-pinene }(6.3 \%) .{ }^{18}\end{array}$ \\
\hline
\end{tabular}

Root: wounds and toothache; ${ }^{22}$ Leaves: used as stimulant, carminative, and to treat coughs and colds, ${ }^{23}$ analgesic,

C. antiseptic, astringent, and glanduliferum carminative properties; ${ }^{24}$ (Wall.) Meisn. Seed: cold, cough, toothache and taenias, muscular swellings, seed oil in treating muscular spasm, joint pain and body aches;' Bark: kidney trouble. ${ }^{25}$
Leaf oil sample of northern India, rich in I,8-cineole (4I.4\%), $\alpha$-pinene (20.3\%), and $\alpha$-terpineol (9.4\%), was found to have antibacterial activity against Gram-positive bacteria (Micrococcus luteus) and Gram-negative bacteria (Escherichiacoli, Pseudomonas aeruginosa, and Aeromonas salmonicida). The high concentration of I,8-cineole likely contributes to its efficacy against coughs and colds.

I,8-Cineole has shown clinical efficacy as a mucolytic and spasmolytic as well as beneficial effects in inflammatory airway diseases such as asthma and chronic obstructive pulmonary disease (COPD). ${ }^{26,27}$

\section{C. tamala} (Buch.-Ham.)

Nees and

Eberm.
Leaves: gastic problems; ${ }^{29}$ spice and flavoring agent. $^{30}$
Root essential oil from Nepal, insecticidal (Culex pipiens, Solenopsis invicta richteri). ${ }^{18}$ Leaf oil from Munsyari, Uttarakhand, antibacterial (Salmonella enterica, Escherichia coli, Pasturella multocida); leaf oil from Logaghat, antibacterial (Pasturella multocida). ${ }^{17}$
Fruit oil from Hetauda, Makwanpur, Nepal, nematicidal (Caenorhabditis elegans, LC50 = $15 \mathrm{I} \mathrm{g} / \mathrm{mL}$ ), insecticidal (Culex pipiens, Reticulitermes virginicus). ${ }^{18}$ Fruit oil from Lucknow, India, insecticidal (Callosobruchus chinensis), antifungal (Aspergillus flavus). ${ }^{25}$
C. glaucescens Hand.-Mazz.
In Manipur, India, the powdered bark is used to treat kidney trouble. ${ }^{25}$
Leaf oil from northern India: I,8-cineole (4I.4\%), $\alpha$-pinene (20.3\%), $\alpha$-terpineol (9.4\%), germacrene D-4-ol (6.1\%) and $\alpha$-thujene $(5.10 \%){ }^{28}$

\begin{abstract}
Root essential oil from Hetauda, Makwanpur, Nepal: camphor (35.0\%), linalool (10.6\%), p-cymene (8.5\%), o-cymene $(6.8 \%)$, and I,8-cineole (6.1\%). ${ }^{18}$ Leaf oil from Jeolikote, Uttarakhand: (E)-cinnamaldehyde (79.4\%), (E)-cinnamyl acetate (3.7\%), linalool (5.4\%). ${ }^{21}$ Leaf oil from Munsyari, Uttarakhand: linalool (52.5\%), (E)-innamaldehyde $26.4 \%$ ), I,8-cineol (4.2\%). ${ }^{17}$ Leaf oil from Lohaghat, Uttarakhand: linalool (29.8\%), camphor (44.0\%), (E)cinnamaldehyde (14.3\%). ${ }^{17}$ Leaf oil from Champawat, Uttarakhand: linalool (24.7\%), camphor (25.5\%), (E)-cinnamaldehyde (30.4\%) .${ }^{17}$ Leaf oil from Pannagar, Uttarakhand: eugenol (65.0\%). ${ }^{17}$ Leaf essential oil from Uttarakhand: (E)-cinnamaldehyde (35.8\%$62.3 \%)$, (E)-cinnamyl acetate (4.7\%-22.7\%), linalool $(5.7 \%-16.2 \%) .{ }^{31}$
\end{abstract}

Fruit essential oil from Hetauda, Makwanpur, Nepal: methyl (E)-cinnamate (40.5\%) I,8-cineole (24.8\%), -terpineol (7.4\%). ${ }^{17}$ Commercial fruit essential oil from Nepal: methyl (E)-cinnamate (I4\%) I,8-cineole (I3\%), -terpineol $(7 \%){ }^{32}$ Leaf oil from northeast India: elemicin (92.9\%). ${ }^{33}$

Panicle oil from Jorhat area of Assam: Linalool (65.00\%), $\alpha$-phellandrene (8.90\%), I-8-cineole (3.96\%), $\alpha$-pinene $(3.40 \%), \beta$-phellandrene (3.00\%), $\beta$-pinene (2.55\%), $\beta$-caryophyllene $(2.55 \%),(Z)$-methyl isoeugenol $(2.05 \%)$ and $\alpha$-farnesene (I.93\%). Stem bark oil from Jorhat area of Assam: $\alpha$-terpineol $(23.30 \%)$, linalool (14.40\%), p-cymene (13.90\%), $\alpha$-pinene $(5.30 \%)$, I,8-cineole $(6.85 \%)$ and $(E)$ methyl cinnamate (3.06\%), $\beta$-pinene (I.40\%), $\alpha$-phellandrene (1.46\%), terpinen-4-ol (1.70\%), (E)-cinnamaldehyde ( $1.50 \%)$, eugenol (1.50\%), $\beta$-caryophyllene (2.85\%) and (Z)-methyl isoeugenol (I.05\%). ${ }^{36}$
C. bejolghota Sweet
Bark and its infusions used to treat cough, cold, toothache, liver complaints, diabetes, gall stones and as mouth fresher; ${ }^{34}$ bone fracture and wonds ${ }^{35}$ 
Table Continued..

\begin{tabular}{|c|c|c|c|}
\hline Plant Name & Ethnopharmacology & Antifungal and Antimicrobial & Essential oil \\
\hline $\begin{array}{l}\text { C. zeylanicum } \\
\text { Breyn }\end{array}$ & $\begin{array}{l}\text { Ground cinnamon is } \\
\text { used in diarrhoea and } \\
\text { dysentery; for cramps } \\
\text { of the stomach, gastric } \\
\text { irritation; for checking } \\
\text { nausea and vomiting; } \\
\text { used externally in } \\
\text { toothache, neuralgia } \\
\text { and rheumatism. The } \\
\text { bark is included in } \\
\text { medicinal preparations } \\
\text { for indigestion, flatulence, } \\
\text { flu, mothwashes, gargles, } \\
\text { herbal teas. }{ }^{37}\end{array}$ & $\begin{array}{l}\text { Bark from Lucknow, antibacterial S. aureus (Gram positive) } \\
\text { and E. coli (Gram-negative), anticancer and apoptotic } \\
\text { activityagainst human breast cancer cell line MDA-MB-23I. }{ }^{38}\end{array}$ & 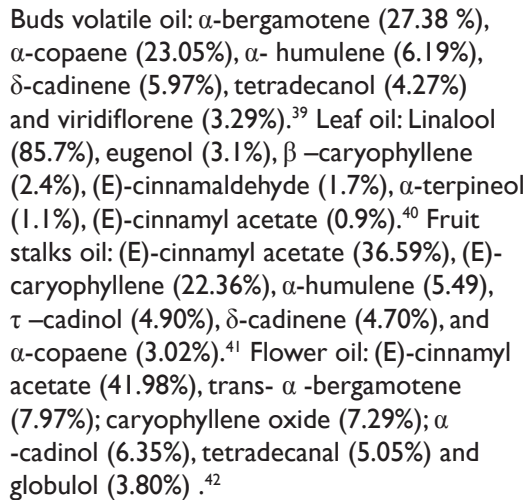 \\
\hline
\end{tabular}

\section{Discussion and Conclusion}

IUCN red listed twenty-four Cinnamomum species. ${ }^{12}$ Cinnamomum are facing great pressure and threat because of economic activities, especially manual picking of bark and fruits as spice and for their medicinal value. Due to the unregulated use and overexploitation, its number is steadily decreasing. If the necessary conservation measures are not adopted, the species could become extinct. Genetic diversity data are important for conservation and management of rare and endangered species. Maintenance of genetic diversity is essential to the long term survival of the tree species without which there may be a risk of its extinction because of lack of adaptive ability. ${ }^{13}$ Cinnamon possess immunomodulatory, antioxidant, antiviral, lowering blood cholesterol, antimicrobial, lipid-lowering, antihypertension, anti-inflammatory, antitumor, gastroprotective, antidiabetic, neuroprotective and blood purifying properties. ${ }^{14}$ Therefore, future conservation and sustainable management programmes for the Cinnamomum species are an urgent priority.

\section{Acknowledgments}

None.

\section{Conflicts of interest}

The author declares that there is no conflict of interests concerning this paper.

\section{References}

1. Sandigwada AM. Genomic studies in some species of cinnamomum schaffer (Lauraceae) as revealed by PCR based DNA market analysis. Ph.D. Thesis, Karnatak Univeristy Dharwad. 2011.

2. Mabberley DJ. Mabberley's plant-book: a portable dictionary of plants, their classifications and uses (No. edition 3). Cambridge University Press. 2008.

3. Imani A, Bani MS, Noori F, et al. The effect of bentonite and yeast cell wall along with cinnamon oil on aflatoxicosis in rainbow trout (oncorhynchus mykiss): Digestive enzymes, growth indices, nutritional performance and proximate body composition. Aquaculture. 2017;476: 160-167.

4. Vangalapati M, Satya NS, Prakash DVS. A review on pharmacological activities and clinical effects of cinnamon species. Research Journal of Pharmaceutical Biological \& Chemical Sciences. 2012;3:653-663.

5. Khasnavis S, Pahan K. Sodium benzoate, a metabolite of cinnamon and a food additive, upregulates neuroprotective Parkinson disease protein dj-1 in astrocytes and neurons. Journal of Neuroimmune Pharmacology. 2012;7(2):424-435.
6. Kim SH, Hyun SH, Choung SY. Anti-diabetic effect of cinnamon extract on blood glucose in $\mathrm{db} / \mathrm{db}$ mice. Journal of Ethnopharmacology. 2006;104(1-2):119-123.

7. De Guzman CC, Siemonsma JS. Plant Resources of South East Asia, No. 13, Spices. Backhys Pub., Lieden. 1999.

8. Coppen JJW. Flavours and Fragrances of Plant Origin, FAO, Rome. 1995.

9. Ravindran PN, Nirmal-Babu K, Shylaja M. Cinnamon and cassia: the genus Cinnamomum. CRC press. 2003.

10. Madan MS, Kannan S. Economics and Marketing of Cinnamon and Cassia-A Global View. In: Ravindran PN, et al., editors. Cinnamon and Cassia: The Genus Cinnamomum (CRC Press: Boca Raton, FL, USA). 2004.

11. Ranatunga J, Senanayake UM, Wijesekera RO. Cultivation and management of cinnamon. In Cinnamon and Cassia. 2003. pp137-145.

12. Oommen S, Ved DK, Krishnan R. Tropical Indian medicinal plants: propagation methods. FRLHT, Foundation for Revitalisation of Local Health Traditions. 2000.

13. Hamrick JL. Genetic diversity and conservation in tropical forests. In Proceedings from the international symposium on genetic conservation and production of tropical forest tree seed. ASEAN-Canadian Forest Tree Seed Centre Project, Muak-Lek, Saraburi, Thailand. 1994.

14. Saeed M, Kamboh A, Syed S, et al. Phytochemistry and beneficial impacts of cinnamon (Cinnamomum zeylanicum) as a dietary supplement in poultry diets. World's Poultry Science Journal. 2018;74(2):331-46.

15. Singh R, Jawaid T. Cinnamomum camphora (Kapur). Pharmacognosy Journal. 2012;4(28):1-5.

16. Pragadheesh VS, Saroj A, Yadav A, et al. Chemical characterization and antifungal activity of Cinnamomum camphora essential oil. Industrial crops and products. 2013;49:628-633.

17. Agarwal R, Pant AK, Prakash O. Chemical composition and biological activities of essential oils of Cinnamomum tamala, Cinnamomum zeylenicum and Cinnamomum camphora growing in Uttarakhand. In Chemistry of Phytopotentials: Health, Energy and Environmental Perspectives. Springer, Berlin, Heidelberg. 2012. p. 87-92.

18. Satyal P, Paudel P, Poudel A, et al. Bioactivities and compositional analyses of Cinnamomum essential oils from Nepal: C. camphora, C. tamala, and C. glaucescens. Natural product communications. 2013;8(12):1777-1784.

19. Inouye S, Yamaguchi $\mathrm{H}$, Takizawa T. Screening of the antibacterial effects of a variety of essential oils on respiratory tract pathogens, using a modified dilution assay method. Journal of Infection and Chemotherapy. 2001;7(4):251-254. 
20. Ho CL, Eugene I, Wang C, et al. Essential oil compositions and bioactivities of the various parts of Cinnamomum camphora Sieb. var. linaloolifera Fujuta. Forestry Research Quarterly. 2009;31(2):77-95.

21. Joshi SC, Padalia RC, Bisht DS, et al. Terpenoid diversity in the leaf essential oils of Himalayan Lauraceae species. Chemistry \& biodiversity. 2009;6(9):1364-1373.

22. Shrestha PM, Dhillion SS. Medicinal plant diversity and use in the highlands of Dolakha district, Nepal. Journal of Ethnopharmacology. 2003;86(1):81-96.

23. Singh C, Singh S, Pande C, et al. Exploration of antimicrobial potential of essential oils of Cinnamomum glanduliferum, Feronia elephantum, Bupleurum hamiltonii and Cyclospermum leptophyllum against foodborne pathogens. Pharm. Biol. 2013;51:1607-1610.

24. Sthapit VM, Tuladhar PM. Sugandha kokila oil: A gift to perfumers from the Himalayan Kingdom of Nepal. Journal of Herbs Spices \& Medicinal Plants. 1993;1(4):31-35.

25. Mikawlrawng K, Kumar S, Vandana R. Current scenario of urolithiasis and the use of medicinal plants as antiurolithiatic agents in Manipur (North East India): a review. International Journal of Herbal Medicine. 2014;2(1):1-12.

26. Worth H, Schacher C, Dethlefsen U. Concomitant therapy with Cineole (Eucalyptole) reduces exacerbations in COPD: a placebo-controlled double-blind trial. Respiratory Research. 2009;10(1):69.

27. Juergens UR. Anti-inflammatory properties of the monoterpene 1.8-cineole: current evidence for co-medication in inflammatory airway diseases. Drug Research. 2014;64(12):638-646.

28. Prakash B, Singh P, Yadav S, et al. Safety profile assessment and efficacy of chemically characterized Cinnamomum glaucescens essential oil against storage fungi, insect, aflatoxin secretion and as antioxidant. Food and chemical toxicology. 2013;53:160-167.

29. Kunwar RM, Uprety Y, Burlakoti C, et al. Indigenous use and ethnopharmacology of medicinal plants in far-west Nepal. Ethnobotany research and applications. 2009;7:005-028.

30. Balami P. Ethnomedicinal uses of plants among the Newar community of Pharping village of Kathmandu District, Nepal. Tribhuvan University Journal. 2004;24(1):13-19.

31. Chanotiya CS, Yadav A. Enantioenriched (3S)-(+)-linalool in the leaf oil of Cinnamomum tamala Nees et Eberm. from Kumaon. Journal of Essential Oil Research. 2010;22(6):593-596.
32. Adhikary SR, Tuladhar BS, Sheak A, et al. Investigation of Nepalese essential oils. I. The oil of Cinnamomum glaucescens (Sugandha Kokila). Journal of Essential Oil Research. 1992;4(2):151-159.

33. Baruah A, Nath SC. Panicle and bark oils of a variant of Cinnamomum bejolghota (Buch-Ham) Sweet. from North East India. Journal of Spices and Aromatic Crops. 2002;11(2):135-137.

34. Gogoi B, Kakoti BB, Borah S, et al. Antihyperglycemic and in vivo antioxidative activity evaluation of Cinnamomum bejolghota (Buch.Ham.) in streptozotocin induced diabetic rats: an ethnomedicinal plant in Assam. Asian Pac J Trop Med. 2014;7:S427-S434.

35. Gogoi B, Kakoti BB, Sharma N, et al. Pharmacognostic and preliminary phytochemical evaluation of Cinnamomumbejolghota (Buch.-Ham.) Sweet bark. Indian Journal of Natural Products and Resources. 2015;7(1):59-64.

36. Baruah A, Nath SC. Leaf essential oils of Cinnamomum glanduliferum (Wall) Meissn and Cinnamomum glaucescens (Nees) Meissn. Journal of Essential Oil Research. 2006;18(2):200-202.

37. Khare CP. Indian medicinal plants: an illustrated dictionary. Springer Science \& Business Media. 2008.

38. Husain I, Ahmad R, Chandra A, et al. Phytochemical characterization and biological activity evaluation of ethanolic extract of Cinnamomum zeylanicum. Journal of Ethnopharmacology. 2018;19:110-116.

39. Jayaprakasha GK, Jaganmohan Rao L, Sakariah KK. Chemical composition of the volatile oil from Cinnamomum zeylanicum Buds. Zeitschrift für Naturforschung. 2002;57(11-12):990-993.

40. Jirovetz L, Buchbauer G, Ruzicka J, et al. Analysis of Cinnamomum zeylanicum blume leaf oil from South India. Journal of Essential Oil Research. 2001;13(6):442-443.

41. Jayaprakasha GK, Jagan Mohan Rao L, Sakariah KK. Volatile constituents from Cinnamomum zeylanicum fruit stalks and their antioxidant activities. Journal of Agricultural and Food Chemistry. 2003;51(15):4344-4348.

42. Jayaprakasha GK, Jaganmohan Rao L, Sakariah KK. Chemical composition of the flower oil of Cinnamomum zeylanicum Blume. Journal of Agricultural and Food Chemistry. 2000;48(9):4294-4295. 